\title{
Article \\ Stock Structure Analysis of the Endangered Queen Loach, Botia dario (Hamilton 1822) from Five Rivers of Northern Bangladesh by Using Morphometrics: Implications for Conservation
}

\author{
Md Sarower Mahfuj 1,2, Fee Faysal Ahmed ${ }^{3} \mathbb{D}$, Md Firoj Hossain ${ }^{4}$, Sk Injamamul Islam ${ }^{1,2}$ (D, Md Jakiul Islam ${ }^{5, *}$, \\ Md Ashraful Alam ${ }^{6}$ (D), Imran Hoshan ${ }^{7}$ and Zubyda Mushtari Nadia ${ }^{8}$ (D)
}

Citation: Mahfuj, M.S.; Ahmed, F.F.; Hossain, M.F.; Islam, S.I.; Islam, M.J.; Alam, M.A.; Hoshan, I.; Nadia, Z.M. Stock Structure Analysis of the Endangered Queen Loach, Botia dario (Hamilton 1822) from Five Rivers of Northern Bangladesh by Using Morphometrics: Implications for Conservation. Fishes 2022, 7, 41. https://doi.org/10.3390/ fishes7010041

Academic Editor: John Waldman

Received: 20 November 2021

Accepted: 3 February 2022

Published: 10 February 2022

Publisher's Note: MDPI stays neutral with regard to jurisdictional claims in published maps and institutional affiliations.

Copyright: (C) 2022 by the authors. Licensee MDPI, Basel, Switzerland. This article is an open access article distributed under the terms and conditions of the Creative Commons Attribution (CC BY) license (https:// creativecommons.org/licenses/by/ $4.0 /)$.
1 Department of Fisheries and Marine Bioscience, Jashore University of Science and Technology, Jashore 7408, Bangladesh; 6378807231@student.chula.ac.th (M.S.M.); 6378506331@student.chula.ac.th (S.I.I.)

2 Department of Veterinary Microbiology, Faculty of Veterinary Science, Chulalongkorn University, Bangkok 10330, Thailand

3 Department of Mathematics, Faculty of Science, Jashore University of Science and Technology, Jashore 7408, Bangladesh; ffa.math@just.edu.bd

4 Department of Fisheries Management, Faculty of Fisheries, Bangladesh Agricultural University, Mymensingh 2202, Bangladesh; firoj14.just@gmail.com

5 Faculty of Biology and Chemistry (FB 02), University of Bremen, 28359 Bremen, Germany

6 Rural Development Academy, Bogura 5801, Bangladesh; ashhstu019@gmail.com

7 Department of Fisheries Biology and Genetics, Faculty of Fisheries, Hajee Mohammad Danesh Science and Technology University, Dinajpur 5200, Bangladesh; imran_fbg17@hstu.ac.bd

8 Department of Aquatic Animal Health Management, Sher-e-Bangla Agricultural University, Dhaka 1207, Bangladesh; zubyda.nadia@sau.edu.bd

* Correspondence: mdjislam@uni-bremen.de

Abstract: Identifying stock is key to sustainable fisheries management and conservation. Using traditional morphometrics (TMR) and image-based truss network analysis (ITNA), we evaluated the stock structure of the endangered queen loach, Botia dario. The study was carried out in the following five stocks in Bangladesh's northern rivers: the Atrai, Dhorala, Danu, Jamuna, and Padma. The inventory regarding stock structure was investigated using a total of nine traditional morphometrics, 11 ratios, and 23 truss measurements for each individual. To generate 23 ITNA, 12 landmarks were used. To assess variations among the stocks, a principal component analysis (PCA), factor analysis (FA), canonical variate analysis (CVA), and cluster analysis (CA) were performed. Six principal components explained $91.50 \%$ of the variation in TMR, while seven principal components explained $73.425 \%$ of the variation in ITNA. CVA, using traditional methods and ratios were correctly classified as $65.0 \%, 42.0 \%, 64.2 \%, 89.3 \%$, and $77.5 \%$ for Danu, Padma, Jamuna, Dhorala, and Atrai River stocks, respectively, based on original grouped classes. CVA using ITNA was correctly classified as $90.0 \%, 80.0 \%, 77.4 \%, 94.6 \%$, and $98.6 \%$ for Danu, Padma, Jamuna, Dhorala, and Atrai River stocks, respectively, based on original grouped classes. CVA analysis based on TMR and ITNA showed that cannonical variates (CV1 to CV3) are related to the whole-body shape. Both TMR and ITNA formed two clusters. In the first cluster, the Jamuna and Atrai River stocks combinedly formed a separate stock based on (TMR). In ITNA, the Dhorala and Atrai River formed as separate stocks from the other four stocks. According to this study, combining TMR and ITNA analysis aids in the differentiation of various $B$. dario stocks. The stock separation of this species was supposed to be geographic disconnection, waterway nature, and temperature variations. The $B$. dario stocks are heavily exploited and the species is an ideal nominee for species variation to boost the aquaculture yield. Within-stock distinctions were revealed in this study, necessitating the identification of gene pools and molecular studies to achieve a deeper understanding of the stocks. Through a more scientific approach, this stock structure study may aid in the development of conservation programs for this endangered species.

Keywords: landmark; truss; Botia dario; morphometric variations; rivers; Bangladesh 


\section{Introduction}

A key aspect of fisheries management is the notion of stock. It forms the basis of the fundamental working groups on which the state of fisheries is assessed and the management policies aimed at ensuring long-term exploitation are executed [1]. A stock is a sporadic group of arbitrarily reproducing individuals with spatial veracity within a species [2,3]. Diverse stock theories arise depending on the operational approach used, such as phenotypic stock, genetic stock, harvest stock, and reproductive stock $[4,5]$. Since each stock must always be regulated singly to ensure productivity, an understanding the stock formation is essential for the systematic and structured management of a fisheries resource [6] and stock information is necessary for any fishery analysis and conservation as well $[7,8]$. Many procedures for stock identification have been recommended, for instance, meristic and morphometrics [9-12], telemetry methods [13-15], chemical compositions and structures of otolith [16], fatty acid profiles [17], pollution analysis [18], and molecular approaches [19]. A scientific data analysis regarding multivariate approaches was used to evaluate variation in advancement and establish among stocks [20]. Modern innovations have been utilized by image-based techniques which allow for a more ample and accurate data assortment and well-organized shape quantification across the fish body [21-23]. These strategies are effective at obtaining information about an individual's shape because they have no limitations on the orientations of variation or the placement of shape changes [24]. Image-processing systems were essential for the development of morphometric strategies, boosting the value of morphometric investigation in fish-stock recognition [25]. Morphometric stock assessments have embodied the evolution of morphometric analysis as an intricate discipline with applications in a wide range of biological disciplines. Morphometric assessment has also been used to identify unknown hybrids, unknown species, and population changes in aquatic organisms [26-28]. Morphological network observations indicate that they are made up of several digital landmark-based points and that they can be used to identify complex and familiar stocks [2,29]. Traditional measurements have long been used in studies of the morphometric features of fish bodies, such as length, width, and depth [26].

The Truss Network System is a landmark-based morphological procedure that places no constraints on the path of variation or the positioning of shape alterations. The trussnetwork infrastructure is indeed very efficient in capturing relevant data about an individual's shape [24]. Truss network measured values are a set of dimensions between landmarks that constitute a consistent pattern of interlinked quadrilaterals throughout the body [30]. Photograph storage also allows for a more adaptable distinctive feature selection and detailed verification of exceptional variants [25]. Those landmarks are characterized by the junction of different organs, such as fin insertion locations and anal pores, and thus the network should resemble the shape of the sample from which it is inferred [31].

Botia dario (Hamilton, 1822), also regarded as queen loach, Bengal loach, or necktie loach, has a dark background with yellow-gold striations. The species is commonly distributed in Southeast Asian countries, such as the northern rivers, streams, and lakes of Bangladesh and India [32]. It is one of the very few small indigenous species (SIS) that includes both edible and decorative assets [33,34]. Owing to its wonderful vertical color pattern, this species has a progressive requirement amongst aquarium fish entrepreneurs [35]. Though the fish species became abundant in Bangladeshi rivers, streams, and temporary low-lying wetlands, significant losses have recently been marked due to serious anthropogenic pressures and frequent climatic alterations [36]. Their food intake includes a wide variety of insects, larvae of small fishes, crustaceans, mollusks, algae, plants, and detritus, reflecting that the fish is carni-omnivorous. From April to August, fish generally reach their peak breeding season [37].

The freshwater species population has declined by an estimated $83 \%$ since 1970 , according to the report from Living Planet Index (LPI) [9]. Freshwater species are also at a frighteningly higher risk of extinction than marine and terrestrial species $[38,39]$. Freshwater biodiversity is under a variety of threats, many of which interact in comprehensive 
ways [40]. Besides these, the loss of biodiversity from freshwater rivers, lakes, and wetlands is three times higher than forest loss [36]. It has been estimated that the natural ecosystem of $B$. dario has decreased by $60 \%$ over the last twenty years [41]. However, these fish species face endangerment due to habitat loss as a result of insecticide use in agricultural expansion, siltation, pulling of stones from river beds and creation of flood control dams, environmental change, over-exploitation, and destruction of spawning grounds, and lack of adequate management [36]. The species has been classified as endangered due to a sharp decline in its population in the natural waters of Bangladesh [41]. There have not been many studies on $B$. dario biology, which includes the length-weight relationship, gonadal maturation, reproductive biology [33,34,42], nutritional value, and proximate composition [43]. However, there are no documents available for this species. Therefore, more research on stock identification is necessary to bridge the knowledge gap for their sustainability and conservation. In addition, special consideration should be given to its aquaculture potential as well as artificial propagation. Henceforth, stock identification research is necessary to begin conservation and management initiatives for the development of long-term capture fisheries. In this context, the key aims of this study are directed at examining the morphometric variations of $B$. dario for stock identification based on traditional morphometrics, ratios (TMR), and image-based truss network analysis (ITNA) analyses.

\section{Materials and Methods}

\subsection{Sampling}

A total of 290 wild Botia dario samples were gathered from five different stocks viz. Atrai, Dhorala, Danu, Jamuna and Padma Rivers (Table 1, Figures 1 and S1). The samples were obtained during the pre-monsoon (April to May 2020) and monsoon (July to August 2020) periods. Samples were gathered independently based on two seasons (pre-monsoon and monsoon) to avoid any seasonal variations in stock identification [20]. Fish samples were gathered straightforwardly from local fishers at 12.00 to $14.00 \mathrm{~h}$ of catching. The samples were composed of both male and female fishes (Table 1). Two types of fishing gears were used, i.e., seine nets (mesh size, $1.2 \mathrm{~cm}$ ) and gill-nets (mesh size, $1.2 \mathrm{~cm}$ ) to collect samples. The obtained fish samples were identified based on external phenotypes according to Talwar and Jhingran [44]. Following identification, the specimens were put on ice and transferred to the lab for further experimentation.

Table 1. Sampling details of Botia dario stock identification.

\begin{tabular}{|c|c|c|c|c|c|c|}
\hline \multirow{2}{*}{ Stocks } & \multirow{2}{*}{$\begin{array}{l}\text { Sample Size } \\
\text { (n) and }\left(\varphi^{\circ} \circlearrowleft^{7}\right)\end{array}$} & \multirow{2}{*}{$\begin{array}{l}\text { Sampling } \\
\text { Location }\end{array}$} & \multirow{2}{*}{$\begin{array}{l}\text { Geographic } \\
\text { Coordinates }\end{array}$} & \multirow{2}{*}{ Date of Collection } & \multicolumn{2}{|c|}{ Total Length $(\mathrm{cm})$} \\
\hline & & & & & Min-Max & Mean (SD) \\
\hline Atrai River & $71(30: 41)$ & Naogaon & $\begin{array}{l}24^{\circ} 55^{\prime} 03.99^{\prime \prime} \mathrm{N} \\
88^{\circ} 44^{\prime} 41.12^{\prime \prime} \mathrm{E}\end{array}$ & $\begin{array}{l}\text { 5-8 April } 2020 \text { and } \\
\text { 15-18 July } 2020\end{array}$ & $7.36-10.54$ & $9.08(0.79)$ \\
\hline Dhorala River & $56(26: 30)$ & Kurigram & $\begin{array}{l}25^{\circ} 49^{\prime} 07.93^{\prime \prime} \mathrm{N} \\
89^{\circ} 40^{\prime} 08.23^{\prime \prime} \mathrm{E}\end{array}$ & $\begin{array}{l}\text { 16-19 April } 2020 \text { and } \\
\text { 4-7 August } 2020\end{array}$ & $6.21-9.46$ & $7.43(0.73)$ \\
\hline Danu River & $60(28: 32)$ & Netrokona & $\begin{array}{l}24^{\circ} 43^{\prime} 02.59^{\prime \prime} \mathrm{N} \\
91^{\circ} 04^{\prime} 54.44^{\prime \prime} \mathrm{E}\end{array}$ & $\begin{array}{l}\text { 10-12 April } 2020 \text { and } \\
20-22 \text { August } 2020\end{array}$ & $7.42-12.03$ & $9.77(0.96)$ \\
\hline Jamuna River & $53(20: 33)$ & Sirajganj & $\begin{array}{l}24^{\circ} 24^{\prime} 06.19^{\prime \prime} \mathrm{N} \\
89^{\circ} 45^{\prime} 40.73^{\prime \prime} \mathrm{E}\end{array}$ & $\begin{array}{l}\text { 27-29 April } 2020 \text { and } \\
\text { 3-5 August } 2020\end{array}$ & $7.53-12.67$ & $8.98(1.13)$ \\
\hline Padma River & $50(20: 30)$ & Rajbari & $\begin{array}{l}23^{\circ} 46^{\prime} 28.03^{\prime \prime} \mathrm{N} \\
89^{\circ} 43^{\prime} 35.62^{\prime \prime} \mathrm{E}\end{array}$ & $\begin{array}{l}\text { 22-25 May } 2020 \text { and } \\
\text { 26-29 August } 2020\end{array}$ & $5.68-11.42$ & $8.96(1.58)$ \\
\hline
\end{tabular}




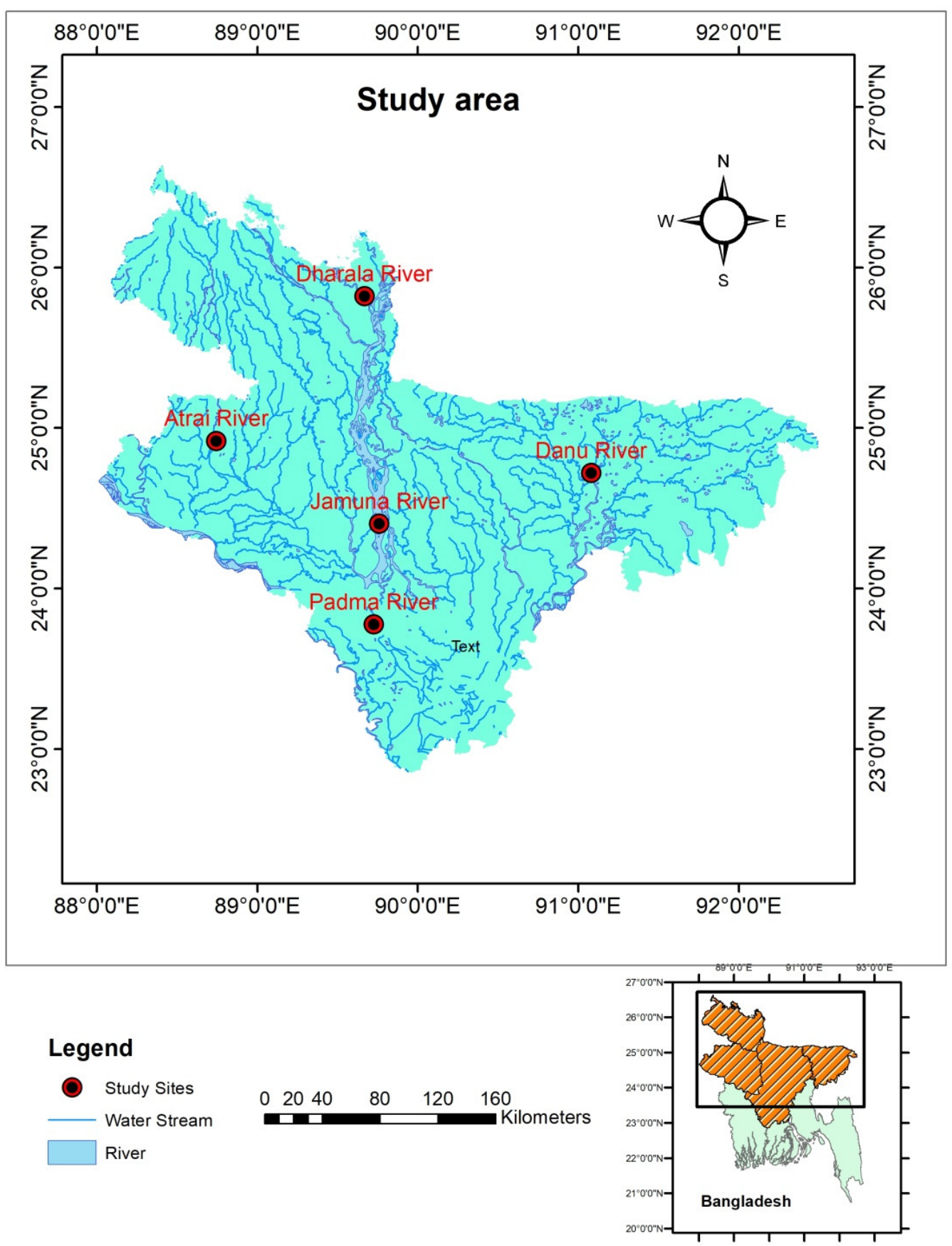

Figure 1. Map showing the collection sites of Botia dario from five rivers of Bangladesh.

2.2. Measurement of Traditional Morphometrics, Ratios (TMR), and Image-Based Truss Network Analysis (ITNA)

Traditional morphometric measurements were taken across the fish body using a vernier caliper with a precision of $0.01 \mathrm{~mm}$. Measurements were recorded from the left to right direction of each specimen $[45,46]$. The nine morphometric characters were measured and described in Table 2. In addition, 12 ratios were incorporated using the 9 morphometric characters (TL_FL, TL_SL, TL_TrL, FL_SL, FL_TrL, SL_TrL, TrL_UCL, TrL_LCL, PrOL_PsOL, TL_UCL, TL_LCL and UCL_LCL). 
Table 2. Nine morphometric characters were used for the analysis of peppered loach, Botia dario stock variations.

\begin{tabular}{cc}
\hline Characters & Description \\
\hline Total length (TL) & $\begin{array}{c}\text { Distance from the tip of the upper jaw to the longest caudal-fin rays } \\
\text { Fork length (FL) } \\
\text { Standard length (SL) } \\
\begin{array}{c}\text { Post orbital head length (PsOL) } \\
\text { Pre-orbital head length (PrOL) } \\
\text { Eye length (EL) } \\
\text { Trunk length (TrL) }\end{array}\end{array} \quad \begin{array}{c}\text { Distance from the tip of the upper jaw to the endpoint of the fork of caudal fin rays } \\
\text { Distance from the tip of the upper jaw to the end of the vertebral column } \\
\text { Distance from the posterior margin of the eye to the end of the operculum } \\
\text { From the front of the upper lip to the fleshy anterior edge of the orbit } \\
\text { A horizontal gap of the eye between the anterior part and posterior part }\end{array}$ \\
$\begin{array}{c}\text { Upper Caudal length (UCL) } \\
\text { The distance between the endpoint of the operculum and the end of the vertebral column } \\
\text { The distance between the upper portion of the caudal fin rays and the end portion of the } \\
\text { upper fin rays }\end{array}$ \\
$\begin{array}{c}\text { The distance between the lower portion of the caudal fin rays and the end portion of the } \\
\text { lower fin rays }\end{array}$ \\
\hline
\end{tabular}

In the case of ITNA, the specimens were first washed in water before being placed on white paper over a smooth surface with the left flank up and the fins raised with pins. The stock was used to code the specimens, and a sample number was assigned for subsequent tracking. The photographs were obtained with a digital camera (Cybershot DSC-W730, Shanghai, China) fixed on a tripod stand. Figure 2 shows photographs depicting the landmarks and truss measurements. The truss network was built using a total of twelve landmarks. For each fish, a truss character with 23 lines joining these twelve landmarks was chosen to represent its basic body from Strauss and Bookstein [30]. The landmarks in the photograph were digitized with the software package 'tpsdig2 v2.1', and the data were archived into tps files in the method of the X-Y coordinate system. The truss lengths were determined by calculating them using unidirectional arrangements of two software applications, tpsDig2 v2.1 [47] and PASTv1.89 [48]. All data were entered into an Excel spreadsheet for further data arrangements as well as transformation to other software applications.

(A)

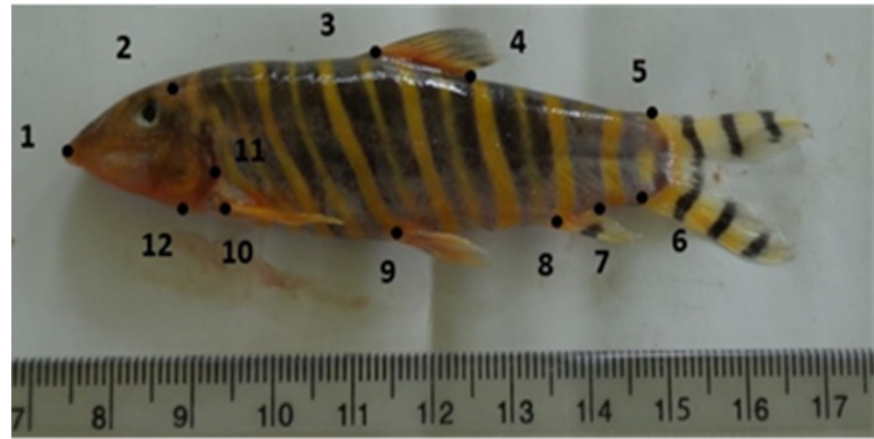

(B)

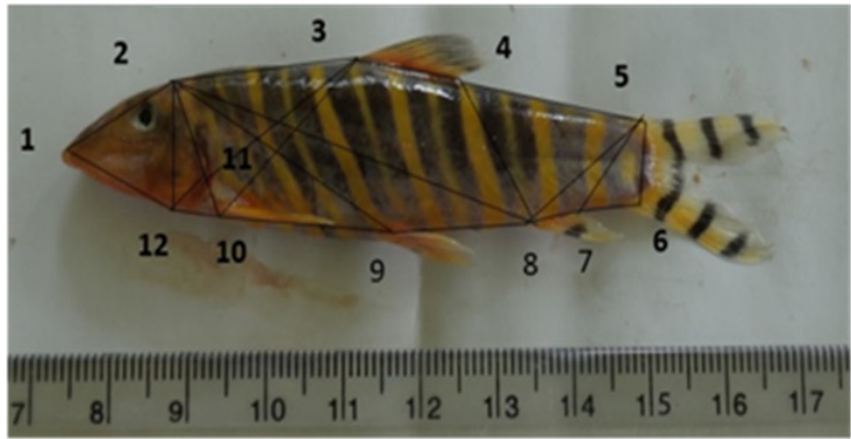

Figure 2. (A) Position of 12 anatomical landmarks of Botia dario for creating 23 truss networks on fish body illustrated as a close circle (black). The explanations of landmarks are followed: (1) anterior tip of the upper snout, (2) origin of the dorsal fin base, (4) endpoint of the dorsal fin base, (5) dorsal origin of caudal fin, (6) ventral origin of the caudal fin, (7) endpoint of the anal fin, (8) origin of anal fin, (9) endpoint of the pelvic fin, (10) origin of pectoral fin, (11) endpoint of opercula, (12) ventral insertion of the opercula. (B) Illustrated photograph of Botia dario comprising 12 landmarks for assembling the truss network.

\subsection{Data Analysis}

Before the analysis, the original measurements (TMR and ITNA) were checked for normality using the Shapiro-Wilk test and Z-scores (skewness/standard error of mean and kurtosis/standard error of mean) that roughly ranged between -1.96 and +1.96 . Then, 
using Paleontological Statistics (PAST v1.89) software, all estimates were logarithmically ( $\log ($ variables)) converted [48]. Next, utilizing total length as a covariate, a multivariate analysis of covariance (MANCOVA) was analyzed to check whether there was any statistically significant difference amongst these chosen study sites. This statistical model examined the effect of total length (covariate), sampling sites, and the interaction between study areas and total length on body morphology (Table S1). After this, all total lengths of each sample were subjected to an independent $T$-test to check for any significant differences between males and females. The independent $T$-test result derived from the TL did not differ significantly between sexes; therefore, data for both sexes (female and male) were accumulated for all statistical experiments. The Pearson correlation result between the TL and the remaining TMR and ITNA characters was highly significant before the allometric transformation. After allometric transformation, none of the morphometric measurements had a substantial correlation with total length, implying that the size effect had been reduced from the data. All of the TMR were subjected to the univariate analysis of variance (ANOVA) to determine whether there was a significant difference. In this regard, the additional analysis did not include the total length (TL), and finally, the TL was curtailed in multivariate analyses. Wilks' lambda test was being used to examine differences between all five stocks and all individuals.

In the case of ITNA, size-dependent variables were rectified using an allometric model, as recommended by Elliott et al. [49] to address the length dependency of each individual. The model is as follows: $M_{a d j}=M\left(L_{0} / L s\right)^{b}$, where $M$ is the initial dimension, $M_{a d j}$ is the size-adjusted dimension, $\mathrm{L}_{0}$ is the total length of each fish, $\mathrm{Ls}$ is the average total length of all fish in each analysis from all samples, and b predicts the slope of the $\log$ and $\log \mathrm{L}_{0}$ regression for all specimens. The significance of the correlation (Pearson model) between the converted variables and total length was tested to reconfirm the allometric method's results [49]. The 23 truss measurements revealed a significant change among five stocks.

A principle component analysis (PCA) was conducted to reduce the magnitudes of the transformed morphometric measurements and ratios together, which could lessen sample redundancy. Based on the PCA components, multivariate models were created, and further analyses, such as canonical variate analysis (CVA) and cluster analysis (CA), were performed with the models' characteristics [50]. The use of a multivariate analysis in many fish morphology experiments can lead to an insufficient sample size. For decades, the proportion of the number of organisms measured $(\mathrm{N})$ to the parameters involved $(\mathrm{P})$ in the analysis has been recommended by researchers of hypothetical works on PCA and CVA [51]. A small number of $\mathrm{N}$ values may not accurately describe covariance or morphological variation, leading to incorrect conclusions about group differences [51]. In this study, all variables were maintained, and the $\mathrm{N} / \mathrm{P}$ proportions were 14.50 and 13.81 for TMR and ITNA, respectively, under these conditions. The contributions of the variables to PCA were investigated to decide which morphometric and truss dimensions most successfully distinguish stock. In this regard, the Kaiser-Meyer-Olkin (KMO) measure and Bartlett's Test of Sphericity were used to assess the data's suitability for PCA. The KMO statistics range from 0 to 1 . According to Kaiser [52], the values are superior to 0.5 and are regarded as suitable. The principles of KMO statistics ranged between 0.5 and 0.7 , which are mediocre, values of 0.7 to 0.8 are good, and 0.8 to 0.9 are outstanding [53]. The values of KMO for the complete matrix in this study were 0.572 and 0.620 for TMR and ITNA, respectively, and Bartlett's Test of Sphericity was significant $(p<0.05)$, indicating that the tested data are appropriate to ensue with a factor investigation process.

In PCA, Jolliffe's rule (eigenvalue $\geq 1.0$ ) was used to choose models and retrieve the major factor contributions for additional analysis. Traits with eigenvalues greater than 1 were included in this analysis, while others were exempted. The Scree test is one way to reduce the number of factors to a number lower than that detected using the 'eigenvalue greater than unity' rule [54]. The eigenvalues were obtained by plotting against the factors in decreasing order along the $X$-axis in this test. The number of components that directly respond to the capacity that seems to change slope is believed to be the number 
of valuable elements eliminated. A factor analysis (FA) was used to compress a large set of variables into a smaller subset of latent variables to highlight the relevant aspects. Factors were carefully selected for FA using Bartlett's Test of Sphericity and the (KMO) with eigenvalues $\geq 1$.0. The factors were exposed to a varimax-rotation process to retrieve variables with high loading after (FA). It is worth noting that factor loading greater than 0.30 is considered critical, 0.40 is more significant and 0.50 or greater is extremely large [55]. Only factors with loadings greater than 0.40 were considered significant in this study. The CVA was used to see whether the individuals within each stock were properly identified as well as to verify its accuracy. CA was used to evaluate multivariate data, with similar observations obtained to find a familiar cluster. Finally, the component loadings were used for further CA analysis to categorize the stock based on PCA and CVA. Multivariate investigations such as PCA and CVA were carried out in R. 3.5.3, while univariate ANOVA was carried out in SPSS 16.0 software. To address the similarity of morphometric characters, the unweighted pair group method with arithmetic mean (UPGMA) and CA was used, which mainly centered on the Euclidean distance between stocks. All the analyses were considered at a 5\% significance level.

\section{Results}

\subsection{Traditional and Ratio Morphometric Analysis}

ANOVA demonstrated significant $(p<0.05)$ differences in all the traditional morphometric measurements and ratios (TMR), excluding those in PrOL and TL_FL characters $(p>0.05)$ (Table S2). Furthermore, in the multivariate analysis, these two characters (PrOL, TL_FL) were finally curtailed.

Six factors with eigenvalues $\geq 1$ were found in a PCA of 20 TMR, accounting for $91.50 \%$ of the variance (Figure S2). The first principal component (PC1) was responsible for $28.47 \%$ of the difference, while the second (PC2), third (PC3), fourth (PC4), fifth (PC5), and sixth (PC6) were responsible for $25.02 \%, 12.08 \%, 10.51 \%, 8.57 \%$, and $6.84 \%$, respectively. The most substantial loadings on PC1 were TL_TrL, TL_SL, TL_LCL, TL_UCL, TrL_LCL, TrL_UCL, TrL, SL, FL, FL_TrL, and SL_TrL (Table S3). Correspondingly, in PC2, the most crucial loadings were FL, SL, PsOL, UCL, LCL, TL_SL, TrL_UCL, and TrL_LCL. The bi-plot revealed that all stocks were mixed and overlapped (Figure 3). Wilk's Lambda tests of CVA analysis found significant changes $(p<0.05)$ in all the stocks' morphometric characters in all functions (Table S4).
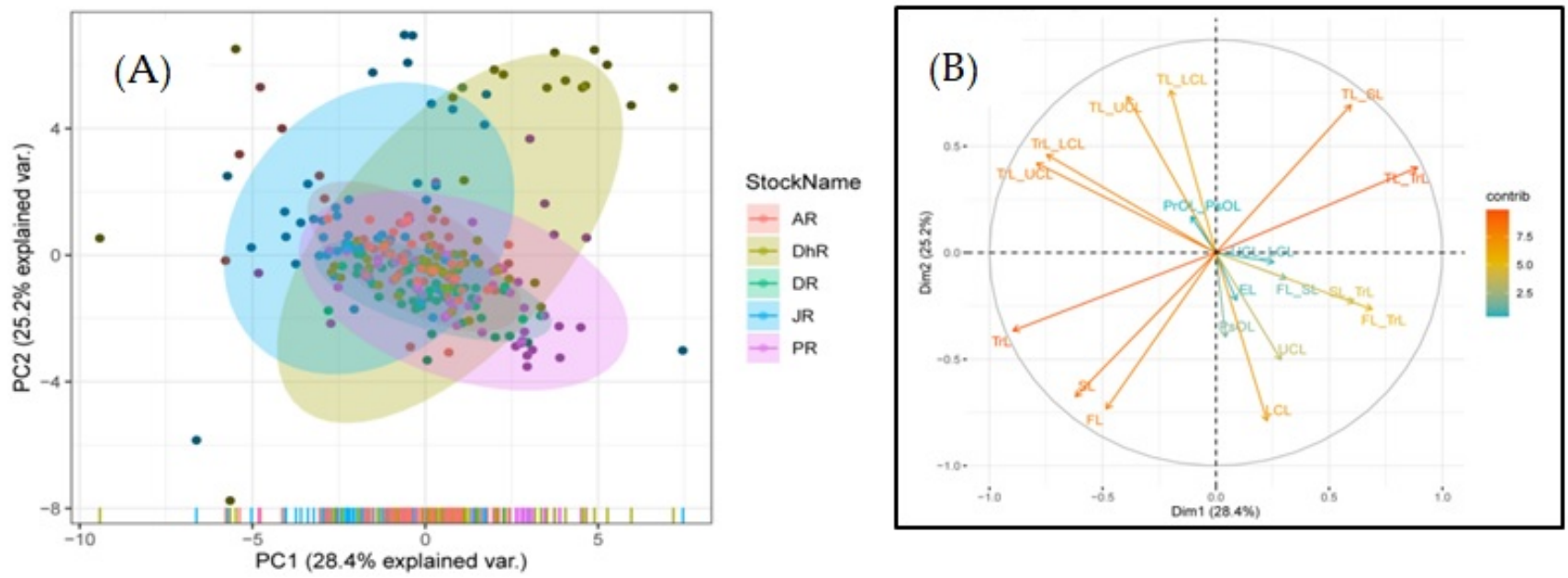

Figure 3. Principal component analysis (PCA) of morphometric data and ratios of Botia dario stocks obtained from five rivers of Bangladesh. (A) bi-plots of PCA are shown and (B) dimension results represent the loadings of each character. 
Four canonical variates were formed using CVA, with CV1, CV2, CV3, and CV4 accounting for $49.1 \%, 29.6 \%, 15.65 \%$, and $5.1 \%$ of the morphological variations, respectively (Table S5). The first three CVAs were taken into consideration for further inferences. FL and TL_SL characters were categorized into the first factor (CV1), which explained $49.1 \%$ of the total variances. TL, UCL, PrOL_PsOL, and EL were categorized in the second factor (CV2) that explained $29.6 \%$ of total variances with meaningful loadings. Similarly, the third factor (CV3) explained $15.6 \%$ of total variances for which meaningful loadings were PsOL, TrL_UCL, TrL_LCL, TL_TrL, TrL, FL_TrL, and SL. The bi-plot (CV1 versus CV2) explained $78.7 \%$ of the total variances between the samples and revealed stock intermingling (Figure 4 and Table S5).
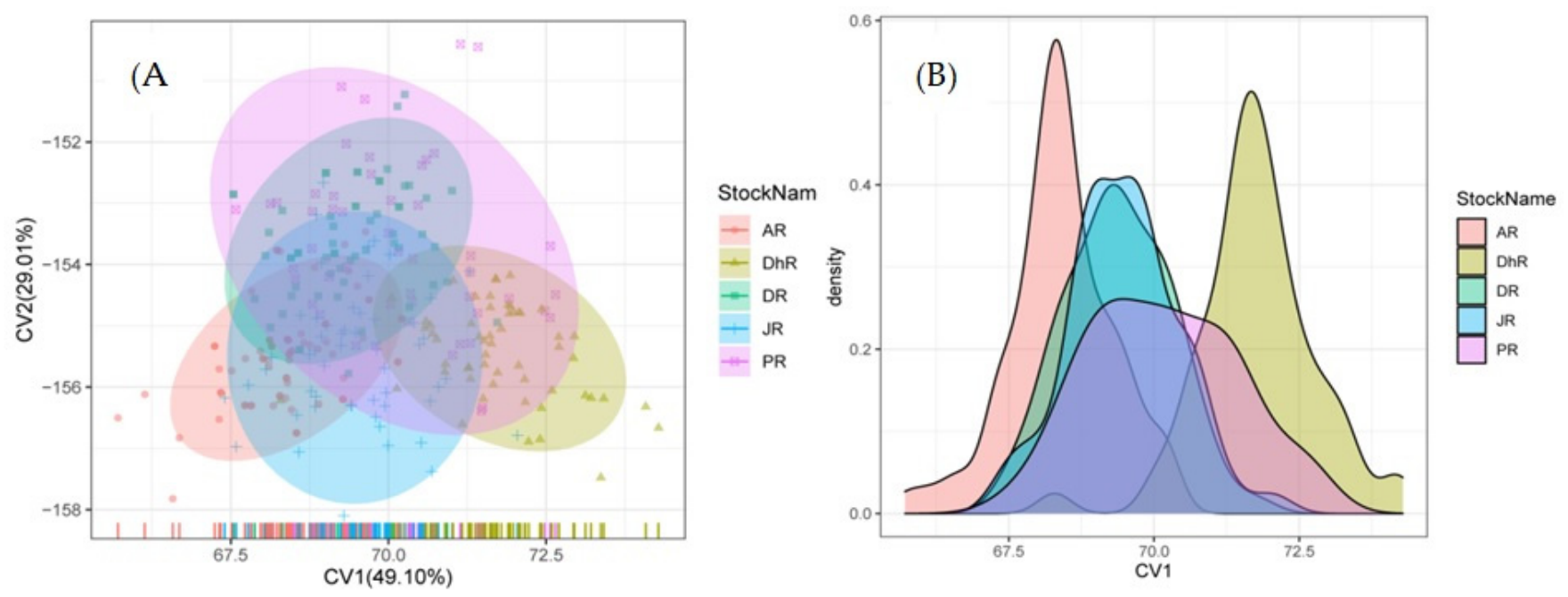

Figure 4. Canonical Variate Analysis (CVA) of morphometric data and ratios of Botia dario stocks obtained from the five rivers of Bangladesh. (A) Bi-plots of sample centroids of the canonical variates scores are shown and (B) density contributions are shown. In the figure, stocks areas are shortened as JR, Jamuna River; AR, Atrai River; DhR, Dhorala River; DR, Danu River, and PR, Padma River.

CVA, using original and cross-validation classification, revealed that $68.6 \%$ and $62.4 \%$ of the individuals were classified as belonging to their original populations, respectively. Original classifications were observed in all stocks, with the Padma River (42.0\%) having the highest level of original classification, followed by the Jamuna (64.2\%), Danu (65.0\%), Atrai $(77.5 \%)$, and Dhorala River (77.5\%). Furthermore, similar findings were found in the cross-validation results, with correct classification rates of $30.0 \%$ in the Padma River, followed by $56.6 \%$ in the Jamuna, $60.0 \%$ in the Danu, $76.1 \%$ in the Atrai, and $76.1 \%$ in the Dhorala River (Table S6).

Two clusters were mainly formed using TMR data (Figure 5). The Jamuna and Atrai River stocks in the first cluster were found to be completely different and formed a separate stock, whereas the Danu and Padma River stocks formed a single sub-cluster. The Jamuna and Atrai rivers had very similar morphological and ratio characteristics; the Danu and Padma rivers had very similar characteristics, hence the Dhorala is also separated from the Danu and Padma River stocks.

\subsection{Image-Based Truss Network Analysis}

In univariate ANOVA, the means of 21 of the 23 truss dimensions were found to be statistically significantly ( $\mathrm{p} 0.05)$ different among five rivers. The remaining two truss measurements, 5-7 and 3-10, were found to be insignificantly different $(p>0.05)$; therefore, they were excluded from the multivariate analysis (Table S7). It is impossible to distinguish stocks from five rivers using a univariate ANOVA analysis. The influences of the variables on principal components (PC) were studied to conclude which truss measurement most effectively segregates stocks. Seven factors with eigenvalues $\geq 1$ were found in a principal 
component analysis of 21 truss measurements, accounting for $73.425 \%$ of the variance (Figure S3). The first (PC1) accounted for $47.88 \%$ of the variation, while the second (PC2), third (PC3), fourth (PC4), fifth (PC5), sixth (PC6), and seventh (PC7) accounted for 24.69\%, $12.62 \%, 9.37 \%, 8.45 \%, 5.515 \%$, and $5.06 \%$, respectively. The most significant loadings on PC1 were 4-5, 6-7, 9-10, 10-11, 2-12, 2-10, 2-9, 2-8, 3-11, 4-10 and 4-8 (Figure 6 and Table S8). Similarly, in PC2, the most significant loadings were 1-2, 3-4, 4-5, 10-11, 12-1, 2-12, and 2-11 (Table S8). The bi-plot reveals that all stocks are mixed as well as intermixed. Variables with loadings were greater than 0.40 found significant in this study.

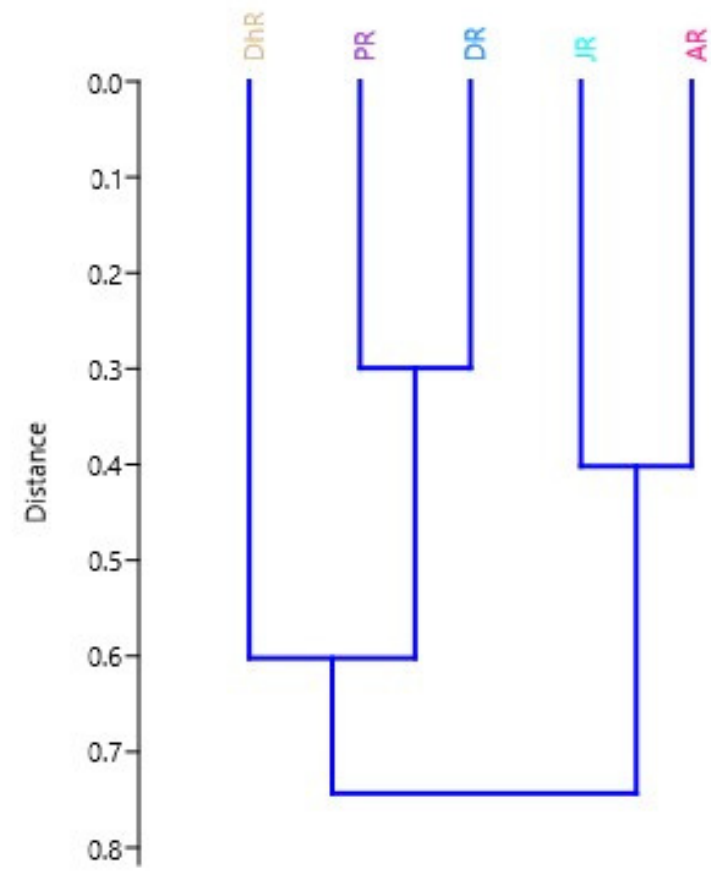

Figure 5. Dendrogram from morphometric measurements and ratios derived from UPGMA cluster analysis based on the Euclidean distance between the species centroids. In the figure, stocks areas are shortened as JR, Jamuna River; AR, Atrai River; DhR, Dhorala River; DR, Danu River, and PR, Padma River.
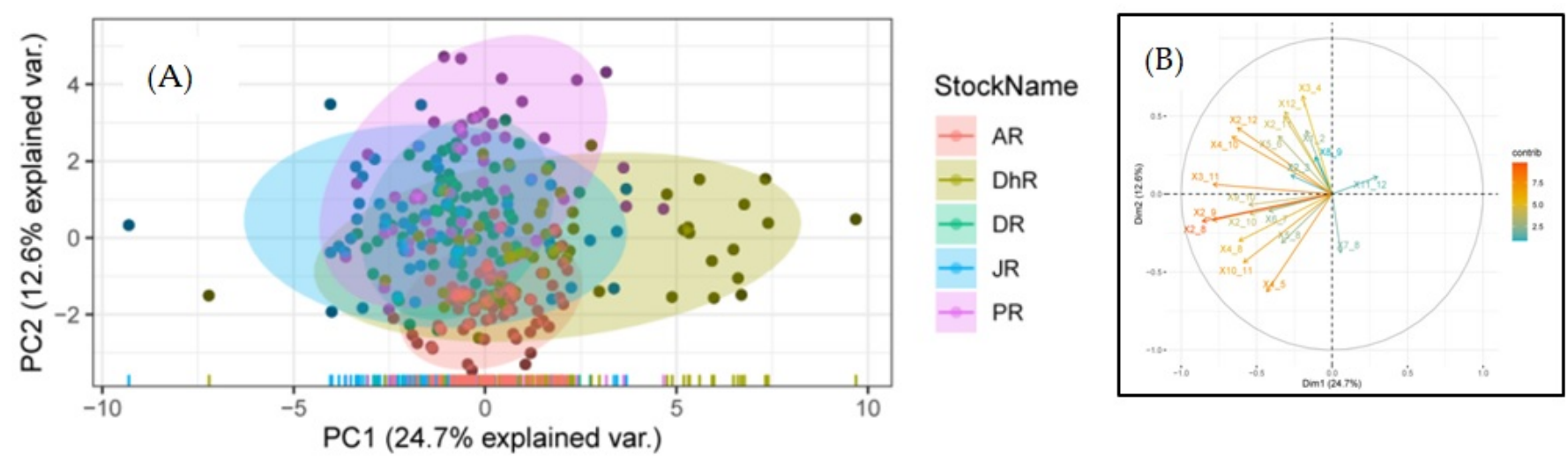

Figure 6. Principal component analysis (PCA) of truss measurements of Botia dario stocks obtained from five rivers of Bangladesh. (A) Bi-plots of principal component analysis are shown and (B) dimension results represent the loadings of each character. 
In all functions (Table S9) significant differences in truss characteristics were revealed $(p<0.05)$. Four canonical variates were formed using CVA, where CV1, CV2, CV3, and CV4 accounted for $65.68 \%, 20.02 \%, 9.90 \%$, and $4.40 \%$ of the morphological variations, respectively (Table S10). For further interpretation, we looked at the first three canonical Variates. With canonical correlations of 0.925 , the truss characters with significant loadings on the first factor (CV1) were 2-11, 7-8, and 6-7 with this factor elucidating $65.68 \%$ of the total variance. Similarly, the truss distances with significant loadings on the second factor (CV2) were 4-10, 2-12, 1-2, 2-3, 11-12, and 3-11 with this factor accounting for $20.0 \%$ of the total variance and canonical correlations of 0.802 , and the third factor (CV3) was 12-1, 4-5, $5-6,2-8,4-8$ and $3-4$ with this factor explaining $9.9 \%$ of the total variance with canonical correlations 0.687 (Table S10). The measurements encompassing the body of the fish are all depicted in the 21 distances. The CV1 versus CV2 plot revealed intermingling among four stocks of PR, JR, DR, and DhR, while AR was completely isolated from the other four stocks, explaining $85.7 \%$ of the total variance among the samples (Figure 7 ).
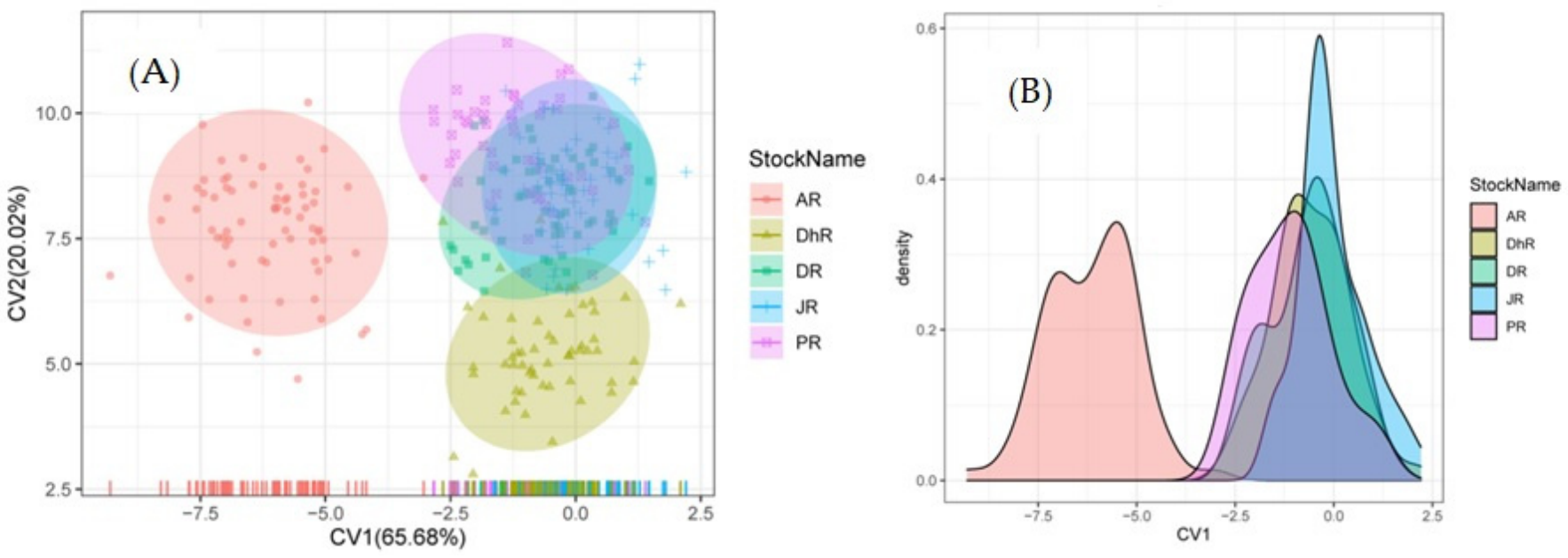

Figure 7. Canonical Variate Analysis (CVA) of truss measurements of Botia dario stocks obtained from the five rivers of Bangladesh. (A) Bi-plots of sample centroids of the canonical variates scores are and (B) density contributions shown. In the figure, stocks areas are shortened as JR, Jamuna River; AR, Atrai River; DhR, Dhorala River; DR, Danu River, and PR, Padma River.

CVA, using original and cross-validation classification, revealed that $89.0 \%$ and $85.9 \%$ of the individuals, respectively, were classified into their original population groups. The maximum correct classification was observed in the Jamuna River $(77.4 \%)$, followed by the Jamuna (80.0\%), Danu (90.0\%), Dhorala (94.6\%), and Atrai River (94.6\%). In addition, similar findings were found in the cross-validation results, with the highest correct classification rates in the Jamuna River (71.7\%), followed by the Padma (74.0\%), Danu (80.7\%), Dhorala (82.1\%), and Atrai River (82.1\%) (Table S11).

The UPGMA was carried out using the Euclidean distance between stocks based on truss character similarity. The dendrogram was created using these distances (Figure 8). The dendrogram revealed that the Dhorala and Atrai Rivers were distinct from the other four stocks and formed their own cluster. Three sub-clusters emerged in the dendrogram, with the Danu and Jamuna River stocks forming one sub-cluster, the Padma stock forming another sub-cluster with the Danu and Jamuna River combinedly. 


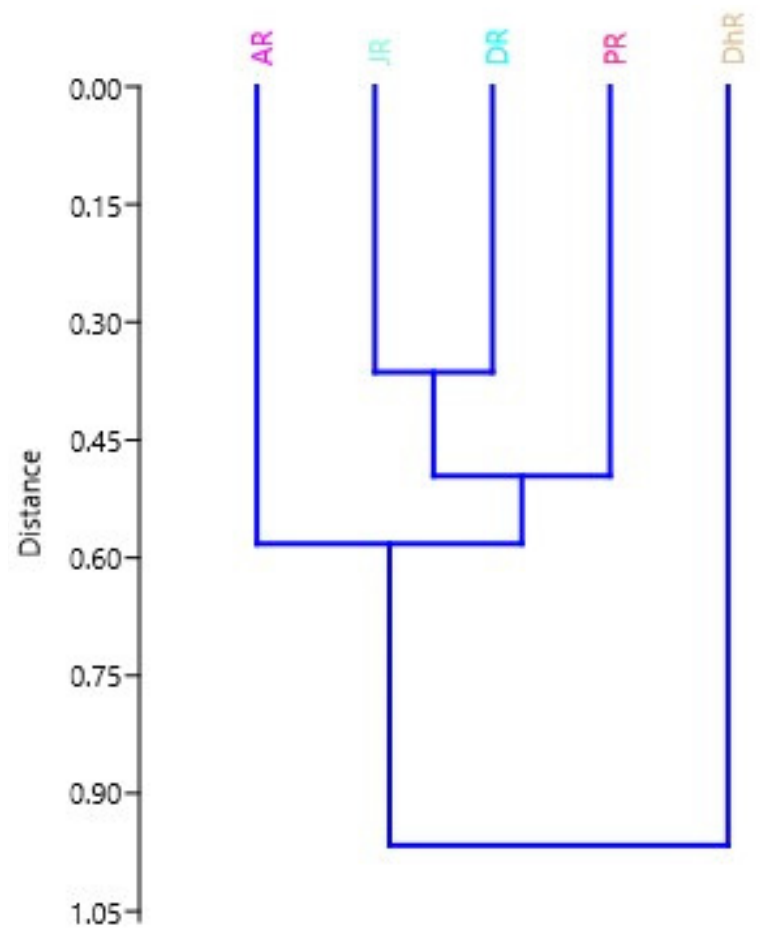

Figure 8. Dendrogram from truss measurements derived from UPGMA cluster analysis based on the Euclidean distance between the stock centroids. In the figure, stocks areas are shortened as JR, Jamuna River; AR, Atrai River; DhR, Dhorala River; DR, Danu River, and PR, Padma River.

\section{Discussion}

The species, Botia dario, is endangered in Bangladeshi rivers, where its abundance has plummeted due to over-harvesting and alterations in the river's ecosystem caused by anthropogenic factors. Incorporating species that are specific to a particular location or are endangered, such as B. dario, into the culture system could improve both production and native species conservation [41]. The evaluation of fish stock configuration is a worthwhile tool for managing natural population groups. One of the most important factors in concluding a valuable inference using a multivariate analysis is having an appropriate sample size. To avoid inaccuracy during analysis, an N:P ratio of at least 3-3.5 is essential [55]. Various studies in this line found a parallel ratio of 4.32 in Capoeta, capoeta gracilis [56], 16.66 in Nandus nandus [57], 14.3 in Labeo rohita [58], 5.89 in Cirrhinus mrigala [59], 3.50 in Chanda nama [60].

Based on the TMR and ITNA, this study elucidated the variations amongst the stocks. Stock interpretation using conventional and truss-based morphometric characteristics was studied in a variety of species, including Nemipterus bipunctatus [61], Xenentodon cancel [62]. In this study, the PCA outlined the framework for ascribing each fish to a specific stock based on the variables of TMR and ITNA. These results must aid in the future estimation of B. dario stocks, as this model could envision the species from the precise location based on the categorized characters. A factor analysis based on traditional and truss morphometry revealed that certain factors (PC1 and PC2) are relevant to the complete body shape. Sajina et al. [63] conducted a study in M. cordyla demonstrated that factors PC1 to PC3 are associated with the head region, body shape, and caudal region, and that trait differences can be elucidated by the hydrological fluctuation of stocks. Using both traditional and truss characters, all stocks were highly intermingled in the bi-plot result of PCA analysis. Similarly, in CVA, body lengths such as FL and ratios (TL_SL) contributed to CV1, caudal length (UCL) and ratios (TL_UCL, PrOL_PsOL and EL contributed to CV2, and head length (PsOL), body length (SL, TrL) and ratios such as TrL_UCL, TrL_LCL, TL_TrL, FL_TrL contributed to CV3. In addition to the use of truss-based morphometric characters in CVA, the entire range of body shapes played a role in CV1, CV2, and CV3. Using traditional 
morphometric characters, all stocks were highly intermingled in the bi-plot result of the CVA analysis, whereas when using truss-based morphometric characters the Atrai River stock was completely isolated from the remaining four stocks (Dhorala, Danu, Padma, and Jamuna Rivers). Several authors explained how phenotypic diversity is affected by water quality parameters [64] and anthropogenic activities [65]. Panda et al. [66] investigated the phenotypic traits of the Indian hill trout, Barilius bendelisis, and discovered that the loadings of traits such as head and body region are influenced by diverse factors, with the purpose of these differences in the body shape being topographical separation and confined genetic diversity. The CVA can also be used to differentiate between stocks of a species, and it is among the most efficient strategies for differentiating phenotypic traits [67]. The four stocks (Padma, Danu, and Jamuna River) were merged based on truss morphometric traits in this study, while the Dhorala and Atrai River stocks were observed in complete isolation from the other stocks. The origins of each stock, on the other hand, are completely different from one another. These phenotypic similarities among the four stocks (Padma, Danu, and Jamuna) could be due to migration during the monsoon season, when heavy rainfall provides ample opportunities for gene pool exchange, resulting in stock amalgamation.

The prediction accuracy (i.e., classification results) based on traditional and trussbased morphometrics revealed that $68.6 \%$ and $89.0 \%$ of individuals were categorized on the original basis, respectively. When compared to TMR and ITNA, they showed high accuracy in CVA. Parallel outcomes were also observed on a cross-validated basis. The classification results based on traditional and truss-based morphometrics revealed that $62.4 \%$ and $85.9 \%$ of species were properly classified, respectively. Hence, the truss measurements would perhaps be sufficient for $B$. dario stock discrimination. However, the accuracy of quantification can be improved by using sophisticated truss distances. Genetic and environmental factors can both influence phenotypic characteristics [68]. Due to the genetic differences resulting from population movement, natural selection, mutation, and environmental influences, the geographical position may lead to different phenotypic characteristics between stocks [67]. For a particular species, any trait can be understood by its biotic factors and location [69]. As clarified by Kumar et al. [70], physiological changes are the primary drivers of phenomic variations in horse mackerel, which could be due to the accessible food or temperature. Differences in morphological characteristics could be caused by adaptations and the rate at which the organisms adapt to those circumstances [71]. Numerous researchers demonstrated how traditional and truss-based morphometric characters can be used to distinguish stocks in population configuration studies using CVA [71,72].

Image processing, in combination with morphometric characters, may also aid in stock segregation and help to develop a deeper understanding of population organization. Nevertheless, based on all of the characteristics examined, variations within stock are minimal. More investigations such molecular-based markers will help to draw more precise conclusions. The size influence is concentrated by allometric transformation, and the lowest differences among stocks based on the investigated characters are due to body shapes and morphometric characters [56]. According to Tzeng [73], morphometric statistical analysis without any conversion or correction yields incorrect output. PCA and CVA, on the other hand, acknowledged the stock discrimination and the contribution between the populations was similar. The association between the stocks could be due to the potential for stock interchange within and between streams.

Based on TMR clusters, it is clear that the Atrai and Jamuna River stocks combinedly outperformed the other stocks (the Padma, Danu, and Dhorala Rivers). On the contrary, the Dhorala and Atrai River stocks were found to be differentiated from the other stocks (the Padma, Danu, and Jamuna Rivers) in the ITNA cluster. Geomorphological features such as the water currents of the Dhorala, Jamuna, and Atrai rivers fall into the lower streams (i.e., the Padma River) of Bangladesh. It was also revealed that the Atrai, Jamuna, and Dhorala stocks require specific management practices. However, both these stocks (the Dhorala, Jamuna, and Atrai Rivers) showed misclassification based on classification results due to their alteration of habitat changes and climatic factors. Despite the fact that 
the Danu River stock was distinct and formed a sub-cluster from the other stocks due to its river origin, the Danu River stock resembled the Jamuna and Padma River stocks in terms of traditional and truss clusters. Such an observable trait difference was observed due to the Danu River stock's diverse sources, and this stock eventually merged with another river called Gomoti and then with the Meghna in Bangladesh. Similar research was carried out to compare the stock structures of three $N$. japonicas across the Indian coast using CA [61]. It can be foreseen that there may be two factors that triggered the stock discrimination. The first is the geographic factor, where two different stocks, the Atrai and Jamuna Rivers, aggregately showed discrimination based on the traditional morphometric clusters, while the Dhorala and Atrai River stock differed from one another based on truss clusters. Traditional morphometric traits and truss measurements could both justify the differentiation among the stocks, as well as the ultimate scenario of the $B$. dario stock structure. The statistical analysis of this experiment is sufficient to distinguish among the stocks. Furthermore, if a large enough sample size is used, this study recommends that traditional and truss morphometric characters can be a trustworthy method for stockidentification research. Research projects of fish stocks conducted in the Bay of Bengal and the Arabian Sea revealed significant alterations due to environmental differences [74]. Consequently, differences in food and feeding habits may have impacted on stocks in the northern and southern river systems, in the present study. According to a different study conducted by Sreekanth et al. [74], geographic segregation and gene-pool interchange resulted in the segregation of horse mackerel stocks. Another concern is abiotic influence, which plays a vital role in stock adjustment [75]. The morphological characteristics of various stocks or populations belonging to the same species may also vary widely. Based on the body-depth of $N$. japonicus, a distinction was presented between the east and west coasts by Sreekanth et al. [74]. The wild stocks of B. dario were used in this study, which could be found in the river basin's lotic waters with less pollution and natural productivity.

The main benefit of conventional methods combined with image processing for stock demarcation is that they aim to recognize different stocks and differentiate between them. When compared to molecular marker-based methods, it is a less expensive and timeconsuming method. Moreover, this is not a time-consuming technology that necessitates data and image acquisition experts. Nevertheless, this technique has the drawback of identifying stock divergence within stocks. The utilization of molecular marker-based techniques is essential to working on the precision of stock design for any hereditary-based breeding program, as well as stock improvement programs.

\section{Conclusions}

Botia dario is a member of the small indigenous species (SIS) and is considered an endangered species in Bangladeshi rivers, because no previous research has been conducted on stock-structure based on traditional and truss morphometric characters. Stockadvancement programs for this endangered species will aid in both increasing fish production and preserving the species. The study of endangered species stock characterization aids in the formulation of conservation programs as well as promoting aquaculture implementations, including cross-breeding and selective breeding. Other recovery initiatives such as habitat protection can be reduced threats to wild species (e.g., by-catch prevention, changes to fishing quotas, endangered species control, or improved habitat condition). On the flip side, the advantage of using genomic tools to enlighten species conservation was accompanied by great enthusiasm. Population genomic exploration for endangered species conservation is unquestionably on the rise. For instance, genomic research has allowed for the creation of panels of DNA barcoding, single nucleotide polymorphism (SNP), and micro-satellite DNA-based markers that can be used to allocate groups of individuals to management entities. More research into the genetic aspects of stock characterization is needed, as this will assist in the advancement of knowledge regarding the stock and the advancement of stock-management practices. 
Supplementary Materials: The following are available online at https:/ /www.mdpi.com/article/ 10.3390/fishes7010041/s1. Figure S1: General appearance of Botia dario. (A) Collected from Atrai River, AR; (B) collected from Dhorala River, DhR; (C) collected from Danu River, DR; (D) collected from Jamuna River, JR; and (E) collected from Padma River, PR. Figure S2: Scree plot of principal component in morphometric measurements and ratios for Botia dario in five rivers of Bangladesh. Figure S3: Scree plot of principal component in morphometric measurements for Botia dario in five rivers of Bangladesh. Table S1: MANCOVA tests for effect of sampling sites, total length (TL) (covariate) and their interaction of body morphology of Botia Dario. Table S2: Univariate ANOVA of morphometric lengths and their ratios of Botia dario stocks collected from the five rivers of Bangladesh. Table S3: Factors loading of different morphometric measurements and their ratios by using PCA among different stocks of Botia dario collected from the five rivers of Bangladesh. Table S4: Wilk's lambda test for verifying differences among stocks of Botia dario with morphometric measurements and ratios, using canonical variate analysis (CVA). Table S5 Contribution of morphometric measurements and ratios to the canonical variate scores in Botia dario collected from five rivers in Bangladesh. Table S6: Classification of Botia dario into their original stocks using classification matrix (original and cross-validated) of the CVA based on morphometric measurements and ratios. Table S7: Univariate ANOVA of morphometric lengths and their ratios of Botia dario stocks collected from the five rivers of Bangladesh. Table S8: Factors loading of truss measurements using PCA among different stocks of Botia dario collected from the five rivers of Bangladesh. Table S9: Wilk's lambda test for verifying differences among stocks of Botia dario with truss measurements using canonical variate analysis (CVA). Table S10: Contribution of truss measurements to the canonical variate scores in Botia dario collected from five rivers in Bangladesh. Table S11: Classification of Botia dario into their original stocks using classification matrix (original and cross-validated) of the CVA, based on truss measurements.

Author Contributions: Conceptualization, M.S.M. and M.J.I.; methodology, M.S.M. and F.F.A.; software, M.S.M. and M.F.H.; validation, M.S.M. and S.I.I.; formal analysis, M.S.M., M.A.A., I.H. and Z.M.N.; investigation, M.S.M.; resources, M.S.M.; data curation, M.F.H., M.A.A., I.H. and Z.M.N.; writing-M.S.M.; writing-review and editing, M.J.I.; visualization, M.S.M. and M.J.I.; supervision, M.S.M. and M.J.I. All authors have read and agreed to the published version of the manuscript.

Funding: This research received no external funding.

Institutional Review Board Statement: Not applicable.

Data Availability Statement: Data are available from first author on reasonable request.

Acknowledgments: The authors are sincerely thankful to the anonymous reviewers for their kind suggestions and comments. Moreover, the Authors are sincerely thankful to the anonymous local fishers for helping during fish sampling. Sincere thanks go to Md Musfike Meraz, current student of Environmental Science Discipline, Khulna University, Bangladesh, for supporting to creation sampling sites figure by using ARC GIS software.

Conflicts of Interest: All authors declare no conflict of interest or involvement in any organization or entity with any financial or non-financial interest in the subject matter or materials discussed in this manuscript.

\section{References}

1. Tanner, S.E.; Reis-Santos, P.; Cabral, H.N. Otolith chemistry in stock delineation: A brief overview, current challenges, and future prospects. Fish. Res. 2016, 173, 206-213. [CrossRef]

2. Ihssen, P.E.; Booke, H.E.; Casselman, J.M.; McGlade, J.M.; Payne, N.R.; Utter, F.M. Stock identification: Materials and methods. Can. J. Fish. Aquat. Sci. 1981, 38, 1838-1855. [CrossRef]

3. Begg, G.A.; Friedland, K.D.; Pearce, J.B. Stock identification and its role in stock assessment and fisheries management: An overview. Fish. Res. 1999, 43, 1-8. [CrossRef]

4. Begg, G.A.; Waldman, J.R. An holistic approach to fish stock identification. Fish. Res. 1999, 43, 35-44. [CrossRef]

5. Abaunza, P.; Murta, A.G.; Campbell, N. Stock identity of horse mackerel (Trachurus trachurus) in the Northeast Atlantic and Mediterranean Sea: Integrating the results from different stock identification approaches. Fish. Res. 2008, 89, 196-209. [CrossRef]

6. Johnson, B.M.; Carpenter, S.R. Functional and numerical responses: A framework for fish-angler interactions? Ecol. Appl. 1994, 4, 808-821. [CrossRef]

7. Bagherian, A.; Rahmani, H. Morphological discrimination between two populations of shemaya, Chalcalburnus chalcoides (Actinopterygii, Cyprinidae), using a truss network. Anim. Bio. Cons. 2009, 32, 1-8. 
8. Clemento, A.J.; Crandall, E.D.; Garza, J.C.; Anderson, E.C. Evaluation of a single nucleotide polymorphism baseline for genetic stock identification of Chinook Salmon (Oncorhynchus tshawytscha) in the California Current large marine ecosystem. Fish. Bull. 2014, 112, 112-130. [CrossRef]

9. World Wild Life (WWF). Living Planet Report. Aiming Higher; Grooten, M., Almond, R.E.A., Eds.; WWF: Gland, Switzerland, 2018.

10. Schwarz, C.J. Estimation of Movement from Tagging Data. In Stock Identification Methods; Elsevier Academic Press: Oxford, UK, 2005; pp. 591-606.

11. Khan, M.A.; Nazir, A. Stock delineation of the long-whiskered catfish, Sperata aor (Hamilton 1822), from River Ganga by using morphometrics. Mari. Fresh. Res. 2018, 70, 107-113. [CrossRef]

12. Ramya, V.L.; Behera, B.K.; Das, B.K.; Krishna, G.; Pavankumar, A.; Pathan, M.K. Stock structure analysis of the endemic fish, Barbodes carnaticus (Jerdon 1849), for conservation in a biodiversity hotspot. Environ. Sci. Pollut. Res. 2021, 1-13. [CrossRef]

13. DeCelles, G.; Zemeckis, D. Acoustic and radio telemetry. In Stock Identification Methods; Elsevier: London, UK, 2013.

14. Hart, K.M.; Hyrenbach, K.D. Satellite telemetry of marine megavertebrates: The coming of age of an experimental science. Endanger. Species. Res. 2009, 10, 9-20. [CrossRef]

15. Metcalfe, J.D.; Wright, S.; Tudorache, C.; Wilson, R.P. Recent advances in telemetry for estimating the energy metabolism of wild fishes. J. Fish. Biol. 2016, 88, 284-297. [CrossRef] [PubMed]

16. Dickhut, R.M.; Deshpande, A.D.; Cincinelli, A. Atlantic bluefin tuna (Thunnus thynnus) population dynamics delineated by organochlorine tracers. Environ. Sci. Technol. 2009, 43, 8522-8527. [CrossRef] [PubMed]

17. Grahl-Nielsen, O. Fatty acid profiles as natural marks for stock identification. In Stock Identification Methods; Academic Press: London, UK, 2005; pp. 247-269.

18. Kerr, L.; Campana, S. Otolith elemental composition. In Stock Identification Methods; Elsevier: London, UK, 2013.

19. Bhattacharya, M.; Sharma, A.R.; Patra, B.C. DNA barcoding to fishes: Current status and future directions. Mito. DNA 2016, 27, 2744-2752. [CrossRef] [PubMed]

20. Cadrin, S.X. Advances in morphometric analysis of fish stock structure. Rev. Fish. Biol. Fish. 2000, 10, 91-112. [CrossRef]

21. Ibáñez, A.L. Fish scale shape variation by year and by geographic location, could scales be useful to trace fish? A case study on the Gulf of Mexico. Fish. Res. 2014, 156, 34-38. [CrossRef]

22. Dryden, I.L.; Mardia, K.V. Statistical Shape Analysis: With Applications in R; John Wiley \& Sons: London, UK, 2016.

23. Ibáñez, A.L.; Hernández-Fraga, K.; Alvarez-Hernández, S. Discrimination analysis of phenotypic stocks comparing fish otolith and scale shapes. Fish. Res. 2017, 185, 6-13. [CrossRef]

24. Cavalcanti, M.J.; Monteiro, L.R.; Lopes, P.R. Landmark-based morphometric analysis in selected species of serranid fishes (Perciformes: Teleostei). Zool. Stud. 1999, 38, 287-294.

25. Cadrin, S.X.; Friedland, K.D. The utility of image processing techniques for morphometric analysis and stock identification. Fish Res. 1999, 43, 129-139. [CrossRef]

26. Park, I.S.; Kim, B.S.; Lee, S.J.; Hur, J.W.; Yoo, J.S.; Song, Y.C.; Kim, Y.J. Comparative morphometric traits of hybrids between red sea bream (Pagrus major) and black sea bream (Acanthopagrus schlegelii). Fish. Aquatic. Sci. 2006, 9, 44-47. [CrossRef]

27. Park, P.J.; Aguirre, W.E.; Spikes, D.A.; Miyazaki, J.M. Landmark-based geometric morphometrics: What fish shapes can tell us about fish evolution. Pro. Asso. Biol. Lab. Edu. 2013, 34, 361-371.

28. Sfakianakis, D.G.; Leris, I.; Laggis, A.; Kentouri, M. The effect of rearing temperature on body shape and meristic characters in zebrafish (Danio rerio) juveniles. Environ. Biol. Fishes 2011, 92, 197-205. [CrossRef]

29. Hüssy, K.; Mosegaard, H.; Albertsen, C.M.; Nielsen, E.E.; Hemmer-Hansen, J.; Eero, M. Evaluation of otolith shape as a tool for stock discrimination in marine fishes using Baltic Sea cod as a case study. Fish. Res. 2016, 174, 210-218. [CrossRef]

30. Strauss, R.E.; Bookstein, F.L. The truss: Body form reconstructions in morphometrics. Syst. Biol. 1982, 31, 113-135. [CrossRef]

31. Rawat, S.; Benakappa, S.; Kumar, J.; Naik, K.; Pandey, G.; Pema, C.W. Identification of fish stocks based on Truss Morphometric: A review. J. Fish Life Sci. 2017, 2, 9-14.

32. Choudhury, T.G.; Das, A.; Battacharjee, P.; Debnath, B. Length-Weight relationship and condition factor of Botia dario (Hamilton) from Gumti River of Tripura, India. Fish Technol. 2012, 49, 215-218.

33. Dey, A.; Sarkar, D.; Barat, S. Spawning biology, embryonic development and captive breeding of vulnerable loach Botia dario (Hamilton). J. Ent. Zool. Stud. 2015, 3, 183-188.

34. Hussain, M.; Khatun, M.; Hossain, M. On the fecundity and sex-ratio of Botia Dario (Hamilton) (Cypriniformes: Cobitidae). Rajshahi Univ. J. Sci. 2008, 26, 27-29. [CrossRef]

35. Gupta, S. A note on the biology of necktie loach, Botia dario (Hamilton, 1822). Int. J. Res. Fish. Aqua. 2016, 6, 1-3.

36. Hossain, M.Y.; Hossen, M.; Ahmed, Z.; Yahya, K.; Rahman, M.M.; Ahamed, F.; Ohtomi, J. Threatened Fishes of the World: Botia dario (Hamilton, 1822) (Cypriniformes: Cobitidae). Ribar. Croat. J. Fish. 2015, 73, 86-88. [CrossRef]

37. Mojumder, N.; Saha, D.; Utsa, S.; Paul, S.; Saha, D. Biology of the endangered queen loach (Botia dario) collected from wild sources in Bangladesh. AACL Bioflux 2020, 13, 2599-2609.

38. Harrison, I.; Abell, R.; Darwall, W.; Thieme, M.L.; Tickner, D.; Timboe, I. The freshwater biodiversity crisis. Science 2018, $362,1369$. [CrossRef] [PubMed]

39. Burkhead, N.M. Extinction Rates in North American Freshwater Fishes; University of California Press: California, CA, USA, 2012; pp. 1900-2010. 
40. Mueller, M.; Pander, J.; Geist, J. Comprehensive analysis of $>30$ years of data on stream fish population trends and conservation status in Bavaria, Germany. Biol. Cons. 2018, 226, 311-320. [CrossRef]

41. Rahman, M.Z. Botia dario. In Red List of Bangladesh Volume 5: Freshwater Fishes; IUCN, International Union for Conservation of Nature, Bangladesh Country Office: Dhaka, Bangladesh, 2015; p. 67.

42. Das, M.K.; Bordoloi, S. Length-weight relationship and reproductive parameters of Botia dario (Hamilton, 1822) in Assam, India. J. Appl. Ichthyol. 2015, 31, 571-573. [CrossRef]

43. Jena, D.; Jena, A.K.; Panda, A.; Parhi, J.; Biswas, P. Proximate analysis of some small indigenous fish species (SIS) of Tripura, India. J. Entomol. Zool. Stud. 2018, 6, 470-474.

44. Talwar, P.K.; Jhingran, A.G. Systematic Account of Siluriformes Fishes. Inland Fishes India Adjacent Countries 1991, 2, 543-714.

45. Gain, D.; Mahfuj, M.S.; Huq, K.A.; Islam, S.S.; Minar, M.H.; Goutham-Bharathi, M.P.; Das, S.K. Landmark-based morphometric and meristic variations of endangered mrigal Carp, Cirrhinus cirrhosus (Bloch 1795) from wild and hatchery stocks. Sains Malay 2017, 46, 695-702. [CrossRef]

46. Samad, M.; Rahman, M.A.; Mahfuj, M.S.; Yeasmin, S.M.; Sultana, M.F.; Ahmed, F.F.; Hossain, M.Y. Life-history traits of ten commercially important small indigenous fish species (SIFS) in the Oxbow lake (Southwestern Bangladesh): Key for sound management. Env. Sci. Poll. Res. 2021, 1-15. [CrossRef]

47. Rohlf, F.J. Stony Brook; tpsDig2, Version 2.1.; State University of New York: New York, NY, USA, 2006.

48. Hammer, Ø.; Harper, D.A.; Ryan, P.D. PAST: Paleontological statistics software package for education and data analysis. Palaeontol. Electron. 2001, 4, 9.

49. Elliott, N.G.; Haskard, K.; Koslow, J.A. Morphometric analysis of orange roughy (Hoplostethus atlanticus) off the continental slope of southern Australia. J. Fish. Biol. 1995, 46, 202-220. [CrossRef]

50. Geladi, P.; Manley, M.; Lestander, T. Scatter plotting in multivariate data analysis. J. Chemom 2003, 17, 503-511. [CrossRef]

51. Kocovsky, P.M.; Adams, J.V.; Bronte, C.R. The effect of sample size on the stability of principal components analysis of truss-based fish morphometrics. Trans. Am. Fish. Soc. 2009, 138, 487-496. [CrossRef]

52. Kaiser, H.F. An index of factorial simplicity. Psychometrika 1974, 39, 31-36. [CrossRef]

53. McGarigal, K.; Cushman, S.A.; Stafford, S. Multivariate Statistics for Wildlife and Ecology Research; Springer Science \& Business Media: London, UK, 2013.

54. Cattell, R.B. The Scree test for the number of factors. Multivariate Behav. Res. 1966, 1, 245-276. [CrossRef]

55. Nimalathasan, B. Determinants of key performance indicators (KPIs) of private sector banks in Sri Lanka: An application of exploratory factor analysis. Ann. Stefan. Cel. Mare. Univ. Suceava. Fac. Econ. Publ. Admin. 2009, 9, 9-17.

56. AnvariFar, H.; Khyabani, A.; Farahman, H.; Vatandoust, S.; AnvariFar, H.; Jahageerdar, S. Detection of morphometric differentiation between isolated up-and downstream populations of Siah Mahi (Capoeta capoeta gracilis) (Pisces: Cyprinidae) in the Tajan River (Iran). Hydrobiologia 2011, 673, 41-52. [CrossRef]

57. Mahfuj, M.S.; Samad, M.A.; Ahmed, F.F.; Alim, M.A.; Bakar, Y.; Das, S.K. Intraspecific Phenotypic Variation in Nearly Threatened Mottled Nandus, Nandus nandus (Hamilton, 1822). Sains. Malays. 2020, 49, 2609-2623. [CrossRef]

58. Mir, J.I.; Sarkar, U.K.; Dwivedi, A.K.; Gusain, O.P.; Jena, J.K. Stock structure analysis of Labeo rohita (Hamilton, 1822) across the Ganga basin (India) using a truss network system. J. Appl. Ichthyol. 2013, 29, 1097-1103. [CrossRef]

59. Dwivedi, A.K. Implications of Physical Barriers on Longitudinal Connectivity in the Ganga River System through Morphological Assessment of Cirrhinus mrigala (Cyprinidae) Populations. J. Ichthyol. 2021, 61, 270-279. [CrossRef]

60. Azad, K.N.; Mahfuj, M.S.; Iqbal, T.; Azad, K.N.; Shafaq, M.A.I. Differentiation of intraspecific phenotypic plasticity of elongate glassy perchlet, Chanda nama: Insights into landmark-based truss morphometric and meristic variations. J. Adv. Vet. Anim. Res. 2020, 7, 585-596. [CrossRef]

61. Vaisakh, G.; Chakraborty, S.K.; Jaiswar, A.K.; Sibina, M.S.; Renjith, R.K.; Sreekanth, G.B. Stock structure analysis of Nemipterus bipunctatus (Valenciennes, 1830) from three locations along the Indian coast. Indian J. Mar. Sci. 2019, 48, 1888-1895.

62. Mahfuj, M.S.; Rahman, M.M.; Islam, M.; Samad, M.A.; Paul, A.K.; Adhikary, R.K. Landmark-based morphometric and meristic variations of freshwater garfish, Xenentodon cancila from four natural stocks of South-Western Bangladesh. J. Adv. Vet. Anim. Res. 2019, 6, 117-124.

63. Sajina, A.M.; Chakraborty, S.K.; Jaiswar, A.K.; Pazhayamadam, D.G.; Sudheesan, D. Stock structure analysis of Megalaspis cordyla (Linnaeus, 1758) along the Indian coast based on truss network analysis. Fish. Res. 2011, 108, 100-105. [CrossRef]

64. Turan, C. A note on the examination of morphometric differentiation among fish populations: The truss system. Turk. J. Zool. $1999,23,259-264$.

65. Mahfuj, M.S.; Das, S.K.; Azad, K.N.; Paul, A.K.; Hoshan, I.; Sultana, S.; Biswas, M. Truss network based morphometric and meristic variations among south-western populations of Macrognathus aculeatus in Bangladesh. J. Environ. Biol. 2021, 42, 887-894. [CrossRef]

66. Panda, A.; Jena, D.; Datta, M.K.; Parhi, J.; Kizhakke, V.R.; Pandey, P.K. Morphological and molecular divergence of Indian hill trout, Barilius bendelisis (Hamilton, 1822) stocks from different Rivers in Indo-Burma biodiversity hotspot: Does river altitude and Dam play a role? J. Appl. Ichthyol. 2019, 35, 1242-1248. [CrossRef]

67. Karakousis, Y.; Peios, C.; Economidis, P.S.; Triantaphyllidis, C. Multivariate analysis of the morphological variability among Barbus peloponnesius (Cyprinidae) populations from Greece and two populations of B. meridionalis and B. meridionalis petenyi. Cybium 1993, 17, 229-240. 
68. Granier, C.; Aguirrezabal, L.; Chenu, K. Phenopsis, an automated platform for reproducible phenotyping of plant responses to soil water deficit in Arabidopsis thaliana permitted the identification of an accession with low sensitivity to soil water deficit. New Phyto. 2006, 169, 623-635. [CrossRef]

69. Haas, T.C.; Blum, M.J.; Heins, D.C. Morphological responses of a stream fish to water impoundment. Biol. Lett. 2010, 6, 803-806. [CrossRef]

70. Kumar, S.P.; Narvekar, J.; Nuncio, M. Is the biological productivity in the Bay of Bengal light limited? Curr. Sci. 2010, 1331-1339.

71. Poulet, N.; Reyjol, Y.; Collier, H.; Lek, S. Does fish scale morphology allow the identification of populations at a local scale? A case study for rostrum dace Leuciscus burdigalensis in River Viaur. Aquat. Sci. 2005, 67, 122-127. [CrossRef]

72. Palma, J.; Andrade, J.P. Morphological study of Diplodus sargus, Diplodus puntazzo, and Lithognathus mormyrus (Sparidae) in the Eastern Atlantic and Mediterranean Sea. Fish. Res. 2002, 57, 1-8. [CrossRef]

73. Tzeng, T.D. Morphological variation between populations of spotted mackerel (Scomber australasicus) off Taiwan. Fish. Res. 2004, 68, 45-55. [CrossRef]

74. Sreekanth, G.B.; Chakraborty, S.K.; Jaiswar, A.K.; Nair, J.R.; Pazhayamadom, D.G.; Renjith, R.K. Site specific differences in food and feeding biology of Nemipterus japonicus (Bloch, 1791) along Indian coast. Indian J. Fish. 2012, 59, $25-31$.

75. Imre, I.; McLaughlin, R.L.; Noakes, D.L.G. Phenotypic plasticity in brook charr: Changes in caudal fin induced by water flow. J. Fish. Biol. 2002, 61, 1171-1181. [CrossRef] 